Jurnal Keperawatan Silampari

Volume 2, Nomor 2, Juni 2019

e-ISSN :2581-1975

p-ISSN :2597-7482

DOI: https://doi.org/10.31539/jks.v2i2.504

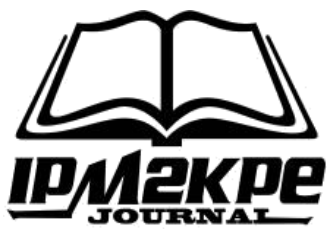

\title{
PENGARUH PELATIHAN MANAJEMEN NYERI TERHADAP PENINGKATAN KOMPETENSI PERAWAT
}

\author{
Adriyanti Amran ${ }^{1}$, Widianingsih ${ }^{2}$, Syamsul Anwar ${ }^{3}$ \\ Puskesmas Pejuang Kota Bekasi Jawa Barat ${ }^{1}$ \\ Program Studi Magister Keperawatan, Universitas Muhammadiyah Jakarta ${ }^{2,3}$ \\ adriyanti_amran@yahoo.com ${ }^{1}$
}

\begin{abstract}
ABSTRAK
Penelitian ini bertujuan untuk menganalisis pengaruh pelatihan manajemen nyeri terhadap peningkatan kompetensi perawat diruangan penyakit dalam dewasa pada rumah sakit Padang Pariaman. Metode penelitian ini menggunakan desain quasieksperiment dengan pendekatan one group pre-post test design. Hasil penelitian diperoleh secara statistik menunjukkan terdapat peningkatan kognitif, afektif dan skill dari manajemen nyeri oleh perawat setelah penelitian secara signifikan $(p<0,05)$. Variabel pengetahuan perawat meningkat dengan nilai 8,647 $\pm 3,427$,sikap 7,882 $\pm 3,789$ dan skil 14,06 menjadi 16,76. Simpulan dari penelitian ini adalah bahwa off the job training sangat potensial dalam meningkatkan kompetensi perawat dalam manajemen nyeri terutama dalam meningkatkan kompetensi kognitif, afektif, dan skill manajemen nyeri. Pelatihan secara berkelanjutan dan evaluasi penerapan mengenai manajemen nyeri, diharapkan dapat meningkatkan kemampuan perawat dalam melaksanakan manajemen nyeri.
\end{abstract}

Kata Kunci: Pelatihan Manajemen Nyeri, Kompetensi, Kognitif, Afektif, Skill

\section{ABSTRACT}

The purpose of this study was to analyze the effect of pain management training on improving nurses' competency in adult diseases in Padang Pariaman hospital. The Method This study uses a quasi-experimental design with one group pre-post test design approach. The results of this study obtained statistically shows that there is an increase in the cognitive, affective and skills of pain management by nurses ( $p<0.05)$. Variable knowledge of nurses increased with a value of 8,647 $\pm 3,427$, attitudes 7,882 $\pm 3,789$ and skills 14,06 to 16,76. The conclusion of this study that Off the job training is very potential for improving nurse competence in pain management, especially in improving cognitive competence, effectiveness, and pain management skills. Continuous training and evaluation of the application of pain management are expected to improve the ability of nurses to carry out pain management.

Keywords: Pain Management Training, Cognitive, Affective, Skill, Competence 


\section{PENDAHULUAN}

Nyeri adalah merupakan suatu rasa yang tidak nyaman, baik ringan maupun berat. Nyeri didefinisikan sebagai suatu keadaan yang mempengaruhi seseorang dan eksistensinya diketahui bila seseorang pernah mengalaminya (Tamsuri, 2007). Menurut International Association for Study of Pain (IASP), nyeri adalah merupakan pengalaman perasaan emosional yang tidak menyenangkan akibat terjadinya kerusakan aktual maupun potensial, atau menggambarkan kondisi terjadinya kerusakan. Menurut Engel yang menyatakan nyeri sebagai suatu dasar sensasi ketidaknyamanan yang berhubungan dengan tubuh dimanifestasikan sebagai penderitaan yang diakibatkan oleh persepsi jiwa yang nyata, ancaman atau fantasi luka (Betz, Sowden, 2012).

Seorang individu pernah mengalami nyeri dalam tingkatan tertentu. Nyeri merupakan alasan paling umum orang mencari perawatan kesehatan. Individu yang merasakan nyeri merasa tertekan atau menderita atau mencari upaya untuk menghilangkan rasa nyeri. Perawat tidak dapat melihat dan merasakan nyeri yang klien rasakan. Nyeri merupakan sumber penyebab frustasi, baik bagi klien maupun tenaga kesehatan. Pengontrolan nyeri tetap merupakan problem signifikan pada pelayanan kesehatan di seluruh dunia. Penanganan nyeri yang efektif tergantung pada pemeriksaan dan penilaian nyeri yang seksama berdasarkan informasi subjektif maupun objektif. Penggunaan munemonik PQRST (Provokatif Quality Region Severity Time) juga akan membantu mengumpulkan informasi vital yang berkaitan dengan proses nyeri pasien (Amelia, 2014).

Nyeri menjadi salah satu alasan pasien mendatangi rumah sakit untuk mencari pertolongan. Menurut Zhang et al, (2013) penatalaksanaan nyeri yang tidak memadai merupakan masalah klinik pada pasien rawat inap yang secara signifikan berpengaruh terhadap psikologis dan keuangan pasien. Lebih jauh dikemukakannya bahwa nyeri yang berkelanjutan berakibat terhadap resiko komplikasi, kecemasan, gangguan tidur dan penurunan kualitas hidup. Senada dengan yang dikemukakan oleh Smeltzer, Bare (2013) bahwa pasien dengan nyeri kronik sering mengalami hambatan dalam melaksanakan aktivitasnya sehari-hari bahkan untuk perawatan diri seperti makan, mandi dan berpakaian, selain itu dapat pula terjadi penurunan dalam hubungan interpersonal mereka.

Nyeri yang diidentifikasi oleh WHO dalam penanganannya sebagai hal yang harus dilaksanakan sehingga menempatkan penanganan nyeri sebagai prioritas. Sedangkan Perserikatan Bangsa Bangsa Chuandy (2015) mendeklarasikan bahwa penanganan nyeri merupakan salah satu hak asasi manusia. Demikian pentingnya penanganan nyeri menjadikan nyeri sebagai vital sign yang kelima, setelah nafas, tekanan darah, nadi dan suhu, sehingga manajemen nyeri mutlak harus ada (Casey, 2011). Berdasarkan Undang-undang nomor 44 tahun 2009 tentang rumah sakit,dikatakan bahwa setiap rumah sakit wajib untuk melaksanakan akreditasi dalam rangka peningkatan mutu pelayanan di rumah sakit minimal dalam jangka waktu 3 (tiga) tahun sekali. Isu manajemen nyeri ini menjadi salah satu elemen penilaian yang dipersyaratkan untuk dipenuhi oleh pihak rumah sakit. Berbagai bentuk pelayanan kesehatan yang diberikan kepada pasien harus mengacu pada pedoman pengelolaan nyeri (Standar Nasional Akreditasi Rumah Sakit \{SNARS\}) (DPD Pormiki, 2017).

Perawat dapat melakukan tindakan mandiri untuk menghilangkan nyeri dalam pelaksanaannya menggunakan teknik manajemen nyeri, misalnya dengan teknik biofeedback, Transcutan Electric Nervous Stimulating (TENS), relaksasi, guided 
imagery, terapi musik, distraksi, terapi bermain, acupressure, aplikasi panas/ dingin, massage, dan hipnosis (Poter, Perry, 2011).

Elemen penilaian dalam akreditasi salah satunya dan angka tata laksana nyeri, manajemen nyeri merupakan salah satu indikator mutu pelayanan keperawatan. Indikator pelayanan keperawatan merupakan indikator mutu minimal yang harus dilaksanakan oleh perawat di rumah sakit. Indikator tersebut meliputi: Keselamatan pasien (patient safety), perawatan diri (self care), kenyamanan (angka tatalaksana nyeri dan angka kenyamanan), kecemasan, pengetahuan dan kepuasan. Menurut Al-Syaer et $a l$, (2011) dalam praktek klinis perawat memiliki peran penting dalam penilaian dan penanganan nyeri serta harus memiliki pengetahuan dalam menilai dan mengelola nyeri. Penelitian yang dilakukannya ini mengatakan bahwa sikap dan pengetahuan perawat memiliki dampak pada manajemen nyeri dan dapat menimbulkan kesalahpahaman dalam manajemen nyeri dan penggunaan opioid. Watson (2013) mengatakan pendidikan mengenai nyeri di institusi pendidikan dan pendidikan berkelanjutan seperti pelatihan bagi perawat perlu untuk meningkatkan pengetahuan perawat mengenai manajemen nyeri.

Saat ini RSUD Padang Pariaman telah ditetapkan sebagai Rumah Sakit Umum Kelas C dengan Kepmenkes RI No.HK.03.05/I/153/2012. Dari studi pendahuluan dan pembicaraan dengan kepala bidang keperawatan di ketahui bahwa rumah sakit ini belum pernah melaksanakan pelatihan manajemen nyeri. Dan melihat dari 7 rekam medis yang diambil secara acak, pendokumentasian pengkajian nyeri dan skala nyeri serta manajemen nyeri yang dilakukan terisi lengkap hanya pada 2 buah status. Selain itu tidak ditemukan pengkajian nyeri dan skala nyeri pada 4 buah status, sedangkan 1 status lagi tidak sesuai antara pengkajian nyeri dan skala nyeri yang ditetapkan, dari hasil wawancara dengan 3 orang perawat, seluruhnya mengatakan belum pernah mendapatkan pelatihan tentang manajemen nyeri, 2 orang perawat mengatakan pengisian pengkajian nyeri dilakukan sesuai dengan pengetahuan yang diperoleh dari pendidikan, satu orang perawat mengatakan ada melakukan pengukuran skala nyeri dan manajemen nyeri, namun tidak mengetahui apakah yang dilakukan sudah sesuai standar atau belum. Dari data tersebut dapat disimpulkan bahwa sebagian besar perawat belum memiliki pengetahuan tentang manajemen nyeri, sebagai dasar untuk melakukan pengkajian dan menerapkan manajemen nyeri tersebut kepada pasien.

\section{METODE PENELITIAN}

\section{Jenis Penelitian}

Penelitian ini menggunakan desain quasi-eksperiment dengan pendekantan one gruppre post test design.

\section{Sampel}

Populasi dalam penelitian ini adalah seluruh perawat yang bekerja di ruangan penyakit dalam dewasa rumah sakit padang pariaman, Seluruh sampel yang digunakan sesuai dengan seluruh jumlah perawat yang bekerja di ruang penyakit dalam dewasa yaitu berjumlah 17 orang dengan kriteria inklusi perawat pelaksana yang bertugas di ruang penyakit dalam dewasa, bersedia menjadi responden, dan bersedia mengikuti pelatihan. Penelitian ini menggunakan jenis pengambilan sampel total sampling. 


\section{Waktu dan Tempat Penelitian}

Penelitian ini dilaksnakan di Rumah Sakit Padang Pariaman, pada tanggal 09 juli 2018 - 05 agustus tahun 2018.

\section{Instrumen Penelitian}

Instrumen dalam penelitian ini terbagi menjadi Kuesioner A yang terdiri dari usia, lama kerja, jenis kelamin, pendidikan, status perkawinan. Kuesioner B terdiri dari pernyataan tentang pengetahuan perawat tentang manajemen nyeri. Skala ukurnya yaitu : $1=$ salah, 2 = benar. Kuesioner $\mathrm{C}$ terdiri dari pernyataan tentang sikap perawat tentang manajemen nyeri Skala ukurnya dengan skala likert yaitu: $1=$ Tidak Pernah (TP), $2=$ Kadang (KD), 3 = Sering (SR), dan $4=$ Selalu (SL). Serta lembar observasi yang terdiri dari observasi untuk skil perawat terhadap manajeman nyeri. Skala ukurnya yaitu $: 1$ = tidak dilakukan, 2 = dilakukan.

\section{Analisis Data}

Penelitian menggunakan analisis univariat dan multivariat. Analisisunivariat dilakukan untuk mendeskripsikan karakteristik dan variabel penelitian, analisis dengan uji $\mathrm{T}$ dependen dan analisi model yang digunakan adalah General linier-repeated measure (GLM_RM) untuk melihat adanya perubahan atau peningkatan pengetahuan, sikap dan skil manajemen nyeri (sebelum intervensi off job training dan setelah intervensi).

\section{HASIL PENELITIAN}

\section{Analisis Univariat}

\section{Gambaran Karakteristik Responden}

Tabel. 1

Data Demografi Distribusi Responden Berdasarkan Usia Lama Kerja (Dalam Tahun)

\begin{tabular}{lccc}
\hline \multicolumn{1}{c}{ Variabel } & N & Mean & SD \\
\hline Usia & 17 & 30,29 & 4,19 \\
Lama Kerja & 17 & 5,12 & 1,799 \\
\hline
\end{tabular}

Hasil analisis data pada Tabel 1 menggambarkan rerata usia responden adalah 30,29 dengan usia perawat termuda adalah 23 dan tertua berusia 40 tahun. Masa kerja responden rata-rata adalah 5,12 tahun dengan masa kerja minimum 2 tahun dan terlama dalah 8 tahun.

Tabel. 2

Data Demografi Distribusi Jenis Kelamin, Pendidikan, dan Status Perkawinan Responden

\begin{tabular}{lcc}
\hline Variabel & Jumlah & Frekuensi (\%) \\
\hline Jenis Kelamin & & \\
a. Laki-laki & 1 & 5,9 \\
b. Perempuan & 16 & 94,1 \\
Pendidikan & & \\
a. D3 Keperawatan & 10 & 58,8 \\
b. S1 Keperawatan / Ners & 7 & 41,2 \\
Status Perkawinan & 2 & 11,8 \\
a. Belum Kawin & 15 & 88,2 \\
b. Kawin & & \\
\hline
\end{tabular}


Dari tabel diatas dapat dilihat bahwa mayoritas responden adalah perempuan $(94,1 \%)$ berpendidikan D3 Keperawatan $(58,8 \%)$ dan sudah menikah $(88,2 \%)$. Hanya 7 orang responden perawat yang memiliki tingkat pendidikan S1 Keperawatan.

\section{Gambaran Skor Kompetensi Manajemen Nyeri Sebelum dan Setelah Intervensi Off the Job Training Manajemen Nyeri}

Tabel. 3

Gambaran Skor Total Kompetensi, Kompetensi kognitif, Afektif, dan Skill Manajemen Nyeri Sebelum dan Setelah Dilakukan Intervensi Off the Job Training Manajemen Nyeri

\begin{tabular}{lcc}
\hline \multicolumn{1}{c}{ Variabel } & Mean & SD \\
\hline Kompetensi Perawat & & \\
Sebelum & 100,588 & 5,112 \\
Setelah & 119,860 & 7,435 \\
\hline Kompetensi kognitif & & \\
Sebelum & 49,12 & 2,643 \\
Setelah & 57,76 & 3,251 \\
\hline Afektif & & \\
Sebelum & 37,41 & 4,757 \\
Setelah & 45,29 & 6,060 \\
\hline Skill & & \\
Sebelum & 14,06 & 1,638 \\
Setelah & 16,76 & 1,091 \\
\hline
\end{tabular}

Dari table Tabel 3 terlihat bahwa nilai rerata skor total kompetensi perawat terhadap manajemen nyeri meningkat dari 100,588 menjadi 119,86. Peningkatan ini juga terlihat pada nilai kompetensi kognitif perawat terhadap manajemen nyeri dimana sebelum mendapatan training manajemen nyeri sebesar 49,12 dan meningkat menjadi 57,76 setelah dilakukan training. Pada kedua variable lainnya yaitu afektif dan skillperawat terhadap manajemen nyeri terdapat kenaikan skor setelah dilakukan training manajemen nyeri. Rerata afektif perawat terhadap manajemen nyeri sebelum

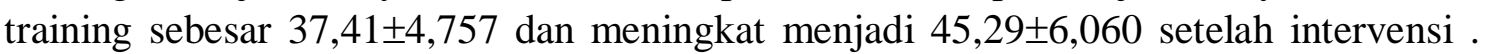
Kemampuan menerapkan manajemen nyeri perawat juga meningkat menjadi

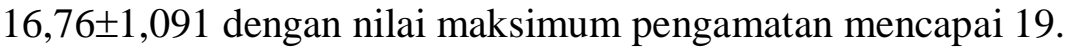

\section{Analisis Bivariat}

Tabel. 4

Hasil Analisis Perbedaan Skor Kompetensi Total, kognitif, Afektif, dan Skill Manajemen Nyeri Sebelum dan Setelah Intervensi Off the Job TrainingManajemen Nyeri

\begin{tabular}{lcccccc}
\hline Penilaian kompetensi & Mean & SD & Mean difference & SD & T & P-Value \\
\hline Kompetensi Total & & & & & & \\
Sebelum & 100,588 & 5,11 & & & \\
Sesudah & 119,824 & 7,44 & 19,24 & 4,777 & 16,604 & 0,000 \\
\hline Kompetensi kognitif & & & & & & \\
Sebelum & 49,12 & 2,634 & 8,647 & 10,404 & 0,000 \\
Setelah & 57,76 & 3,251 & & & & \\
\hline Afektif & 37,41 & 4,757 & 7,882 & 3,789 & 8,576 & 0,000 \\
Sebelum & 45,29 & 6,060 & & & & \\
Setelah & & & & &
\end{tabular}




\begin{tabular}{lcccccc}
\hline Penilaian kompetensi & Mean & SD & Mean difference & SD & T & P-Value \\
\hline Kompetensi Total & & & & & & \\
Sebelum & 100,588 & 5,11 & & & & \\
Sesudah & 119,824 & 7,44 & 19,24 & & & \\
\hline Skill & & & & 1,777 & 16,604 & 0,000 \\
Sebelum & 14,06 & 1,638 & 2,706 & 7,948 & 0,000 \\
Setelah & 16,76 & 1,091 & & & & \\
\hline
\end{tabular}

Tabel 4 menunjukkan bahwa secara statistik terdapat perbedaan antara nilai kompetensi total, nilai kompetensi kognitif, afektif, dan skill manajemen nyeri sebelum dan setelah dilakukan intervensi off job training $(\mathrm{p}<0,05)$. Nilai total kompetensi manajemen nyeri meningkat sebesar 19,24 yang berarti ada perbedaan antara kompetensi sebelum dna setelah dilakukan intervensi $(\mathrm{p}=0,000)$. Pada variabel kompetensi kognitif tampak peningkatan sebesar 8,647 $\pm 3,427$ setelah dilakukan intervensi dengan nilai $\mathrm{p}=0,000$. Rerata afektif perawat terhadap manajemen nyeri juga meningkat sebesar 7,882 $\pm 3,789$ dan menunjukkan perbedaan yang signifikan dengan nilai $\mathrm{p}=0,000$. Perbedaan signifikan juga tampak pada skill manajemen nyeri $(\mathrm{p}=0,000)$ dimana terdapat peningkatan nilai sebelum intervensi 14,06 menjadi 16,76.

Analisis Model General Linear Model-Repeated Measure (GLM-RM) Off Job Training Manajemen Nyeri terhadap Kompetensi kognitif, Afektif, dan Skill Manajemen Nyeri

Tabel. 5

Distribusi Rata-Rata Skor Kompetensi Total, Kompetensi Kognitif, Afektif dan Skill Manajemen Nyeri Tiap Tahap Pengukuran Sebelum dan Setelah Intervensi Off Job Training Manajemen Nyeri

\begin{tabular}{lcc}
\hline \multicolumn{1}{c}{ Variabel } & Mean & SD \\
\hline Kompetensi Total & 100,59 & 5,11 \\
Pengukuran ke-1 & 114,82 & 7,72 \\
Pengukuran ke-2 & 117,88 & 7,26 \\
Pengukuran ke-3 & 119,82 & 7,44 \\
Pengukuran ke-4 & & \\
\hline Kompetensi kognitif & 49,12 & 2,643 \\
Pengukuran ke-1 & 53,00 & 3,102 \\
Pengukuran ke-2 & 55,94 & 3,191 \\
Pengukuran ke-3 & 57,76 & 3,251 \\
Pengukuran ke-4 & & \\
\hline Afektif & 37,41 & 4,757 \\
Pengukuran ke-1 & 45,65 & 5,947 \\
Pengukuran ke-2 & 45,47 & 5,938 \\
Pengukuran ke-3 & 45,29 & 6,060 \\
Pengukuran ke-4 & & \\
\hline Skill & 14,06 & 1,638 \\
Pengamatan ke-1 & 16,18 & 1,185 \\
Pengamatan ke-2 & 16,47 & 1,125 \\
Pengamatan ke-3 & 16,76 & 1,091 \\
Pengamatan ke-4 & & \\
\hline
\end{tabular}


Tabel 5 menunjukkan bahwa terjadi peningkatan nilai rerata kompetensi total, subkompetensi kognitif, afektif, dan skill manajemen nyeri dari sebelum dilakukan intervensi (pengamatan ke-1) dan setelah dilakukan intervensi (pengamatan ke-2, ke-3, dan ke-4). Peningkatan rerata yang signifikan tampak pada variable kompetensi total dan sub kompetensi kognitif dimana peningkatan terjadi pada minggu pertama $(100,59$ dan 49,12) sampai minggu ke empat $(119,82$ dan 57,76).. Sementara itu, kedua variable afektif dan skill menunjukkan gambaran yang berbeda. Afektif dan skill manajemen nyeri perawat meningkat drastis pada pengukuran ke-2 (minggu pertama setelah intervensi) dan cenderung menetap hingga minggu ke-4. Rerata afektif responden meningkat dari 37,41 menjadi 45,65 dan cenderung menetap sampai minggu ke-4 sebesar 45,29. Skor skill manajemen nyeri juga menunjukkan hal serupa meningkkat di minggu ke-2 menjadi 16,18 dan menetap sampai minggu ke-empat $(16,76)$.

\section{Uji Multivariat}

Tabel. 6

Distribusi Multivariat Perbedaan Kompetensi Total, Kompetensi Kognitif, Afektif, dan Skill Manajemen Nyeri Sebelum dan Setelah Intervensi Off the Job Training Manajemen Nyeri anatara Keempat Pengukuran

\begin{tabular}{lc}
\hline Effect & p-value \\
\hline Kompetensi Total & \\
Pillai's trace & 0,000 \\
Wilks lambda & 0,000 \\
Hotteling's trace & 0,000 \\
Roy's largest root & 0,000 \\
\hline Kompetensi kognitif & \\
Pillai's trace & 0,000 \\
Wilks lambda & 0,000 \\
Hotteling's trace & 0,000 \\
Roy's largest root & 0,000 \\
\hline Afektif & \\
Pillai's trace & 0,000 \\
Wilks lambda & 0,000 \\
Hotteling's trace & 0,000 \\
Roy's largest root & 0,000 \\
\hline Skill & \\
Pillai's trace & 0,000 \\
Wilks lambda & 0,000 \\
Hotteling's trace & 0,000 \\
Roy's largest root & 0,000 \\
\hline
\end{tabular}

Hasil uji multivariat menunjukkan bahwa terdapat perbedaan kompetensi total, kompetensi kognitif, afektif, dan skill manajemen nyeri setelah mendapatkan intervensi terhadap manajemen nyeri $(\mathrm{p}<0,05)$ yang berarti terdapat perbedaan rerata skor kompetensi kognitif, afektif, dan skill manajemen nyeri antar keempat pengamatan. 


\section{Asumsi Error Kovarian Matriks Proporsional antar variable Dependen (Asumsi Sphericity)}

Tabel. 7

Pemenuhan Asumsi Sphericity

\begin{tabular}{|c|c|c|c|c|c|c|c|}
\hline \multirow[t]{2}{*}{ Within subject effect } & \multirow{2}{*}{$\begin{array}{l}\text { Munchly } \\
\text { 's W }\end{array}$} & \multirow{2}{*}{$\begin{array}{l}\text { Approx } \\
\text {. chi- } \\
\text { square }\end{array}$} & \multirow[b]{2}{*}{ Df } & \multirow[b]{2}{*}{ P-value } & \multicolumn{3}{|l|}{ Epsilon } \\
\hline & & & & & $\begin{array}{l}\text { Greenhouse } \\
\text {-geisser }\end{array}$ & $\begin{array}{l}\text { Huynh- } \\
\text { feldt }\end{array}$ & $\begin{array}{l}\text { Lower- } \\
\text { bound }\end{array}$ \\
\hline Komptensi Total & 0,164 & 26,634 & 5 & 0,000 & 0,650 & 0,739 & 0,333 \\
\hline Kompetensi kognitif & 0,001 & 96,661 & 5 & 0,000 & 0,349 & 0,352 & 0,333 \\
\hline Afektif & 0,174 & 25,763 & 5 & 0,000 & 0,535 & 0,585 & 0,333 \\
\hline Skill & 0,136 & 29,396 & 5 & 0,000 & 0,485 & 0,521 & 0,333 \\
\hline
\end{tabular}

Hasil analisis menunjukkan bahwa asumsi pemenuhan sphercity tidak terpenuhi $\mathrm{p}=0,000 \quad(\mathrm{p}<0,05)$ yang bermakna bahwa covarian matriks variable dependen kompetensi total, kompetensi kognitif, afektif, dan skill tidak proporsional. Karena hal ini, maka selanjutnya nilai uji Greenhouse-Geisser akan menjadi acuan dalam menentukan perbedaan kompetensi total, kompetensi kognitif, afektif, dan skill manajemen nyeri antar pengamatan (within subject effect).

\section{Test Perbedaan Nilai antar Pengukuran (Test of Within-Subject Effects)}

Tabel. 8

Test of Within-Subject Effects

\begin{tabular}{lcc}
\hline \multicolumn{1}{c}{ Source } & p-value & Partial Eta Squared \\
\hline Kompetensi Total & & \\
Sphericity Assumed & 0,000 & 0,906 \\
Greenhouse-Geisser & 0,000 & 0,906 \\
Huynh-Feldt & 0,000 & 0,906 \\
Lower-bound & 0,000 & 0,906 \\
\hline Kompetensi kognitif & & \\
Sphericity Assumed & 0,000 & 0,844 \\
Greenhouse-Geisser & 0,000 & 0,844 \\
Huynh-Feldt & 0,000 & 0,844 \\
Lower-bound & 0,000 & 0,844 \\
\hline Afektif & & \\
Sphericity Assumed & 0,000 & 0,760 \\
Greenhouse-Geisser & 0,000 & 0,760 \\
Huynh-Feldt & 0,000 & 0,760 \\
Lower-bound & 0,000 & 0,760 \\
\hline & & \\
Skill & & 0,773 \\
Sphericity Assumed & 0,000 & 0,773 \\
Greenhouse-Geisser & 0,000 & 0,773 \\
Huynh-Feldt & 0,000 & 0,733 \\
Lower-bound & 0,000 & \\
\hline
\end{tabular}

Tabel Test of Within-Subjects Effects menunjukkan nilai p pada uji GreenhouseGeisser $<0,05$ menunjukkan adanya perbedaan skor kompetensi total maupun pada kompetensi kognitif, afektif, dan skill manajemen nyeri antar pengukuran. Perbedaan secara spesifik dapat dilihat pada table Test Within-Subject Contrast (tabel. 8) yang 
menunjukkan perbedaan nilai rerata kompetensi total, kognitif, afektif, dan skill manajemen nyeri antara pengukuran ke-2, ke-3, dan ke-4 terhadap pengukuran pertama.

Tabel. 9

Test of Within-Subject Contrasts

\begin{tabular}{lcc}
\hline Source & p-value & Partial Eta Squared \\
\hline Kompetensi Total & & \\
Pengukuran 2 vs. Pengukuran 1 & 0,000 & 0,934 \\
Pengukuran 3 vs. Pengukuran 1 & 0,000 & 0,864 \\
Pengukuran 4 vs. Pengukuran 1 & 0,001 & 0,523 \\
\hline Kompetensi kognitif & & \\
Pengukuran 2 vs. Pengukuran 1 & 0,000 & 0,891 \\
Pengukuran 3 vs. Pengukuran 1 & 0,017 & 0,309 \\
Pengukuran 4 vs. Pengukuran 1 & 0,819 & 0,003 \\
\hline Afektif & & \\
Pengukuran 2 vs. Pengukuran 1 & 0,000 & 0,737 \\
Pengukuran 3 vs. Pengukuran 1 & 0,000 & 0,893 \\
Pengukuran 4 vs. Pengukuran 1 & 0,001 & 0,504 \\
\hline Skill & & \\
Pengamatan 2 vs. Pengamatan 1 & 0,000 & 0,793 \\
Pengamatan 3 vs. Pengamatan 1 & 0,000 & 0,734 \\
Pengamatan 4 vs. Pengamatan 1 & 0,000 & 0,608 \\
\hline
\end{tabular}

Hasil analisis Within-Subject Contrasts menunjukkan terdapat perbedaan rerata pegetahuan pada pengamatan ke-2 dan ke-3 terhadap pengamatan ke-1 ( $\mathrm{p}<0,05)$. Pada pengamatan ke-4 terhadap pengamatan ke-1, analisis menunjukkan bahwa tidak terdapat perbedaan skor kompetensi kognitif dengan $\mathrm{p}=0,819$. Sementara itu, variable kompetensi total, afektif dan skill manajemen nyeri menunjukkan perbedaan yang signifikan pada setiap pengamatan $(\mathrm{p}<0,05)$. Skor afektif manajemen nyeri perawat berbeda pada pengamatan ke-2, ke-3, dan ke-4 terhadap pengamatan ke-1 $(\mathrm{p}<0,05)$. Perbedaan juga tampak pada skill manajemen nyeri pengamatan ke-2, ke-3, dan ke-4 setelah intervensi off job training manajemen nyeri terhadap pengamatan ke-1 $(\mathrm{p}=0,000)$.

\section{Parameter Estimates}

Tabel. 10

Parameter Estimates Skor Kompetensi kognitif, Afektif, dan Skill Manajemen Nyeri

\begin{tabular}{lccc}
\hline \multicolumn{1}{c}{ Variabel Dependen } & Parameter & P-value & Partial Eta Squared \\
\hline Kompetensi Total & & & \\
Pengukuran ke-1 & Intercept & 0,000 & 0,998 \\
Pengukuran ke-2 & Intercept & 0,000 & 0,996 \\
Pengukuran ke-3 & Intercept & 0,000 & 0,996 \\
Pengukuran ke-4 & Intercept & 0,000 & 0,996 \\
& & & \\
\hline Kompetensi kognitif & & & 0,997 \\
Pengukuran ke-1 & Intercept & 0,000 & 0,997 \\
Pengukuran ke-2 & Intercept & 0,000 & 0,997 \\
Pengukuran ke-3 & Intercept & 0,000 & 0,997 \\
Pengukuran ke-4 & Intercept & 0,000 & \\
\hline Afektif & & & 0,985 \\
Pengukuran ke-1 & Intercept & 0,000 & \\
\hline
\end{tabular}




\begin{tabular}{lccc}
\hline \multicolumn{1}{c}{ Variabel Dependen } & Parameter & P-value & Partial Eta Squared \\
\hline Kompetensi Total & & & \\
Pengukuran ke-1 & Intercept & 0,000 & 0,998 \\
Pengukuran ke-2 & Intercept & 0,000 & 0,996 \\
Pengukuran ke-3 & Intercept & 0,000 & 0,996 \\
Pengukuran ke-4 & Intercept & 0,000 & 0,996 \\
& & & 0,984 \\
\hline Pengukuran ke-2 & Intercept & 0,000 & 0,984 \\
Pengukuran ke-3 & Intercept & 0,000 & 0,983 \\
Pengukuran ke-4 & Intercept & 0,000 & \\
& & & 0,987 \\
Skill & & & 0,995 \\
Pengamatan ke-1 & Intercept & 0,000 & 0,996 \\
Pengamatan ke-2 & Intercept & 0,000 & 0,996 \\
Pengamatan ke-3 & Intercept & 0,000 & \\
Pengamatan ke-4 & Intercept & 0,000 & \\
& & & \\
\hline
\end{tabular}

Hasil tes pada table 10 menunjukkan ada perbedaan rerata nilai kompetensi total maupun kompetensi kognitif, afektif, dan skill manajemen nyeri sebelum dan setelah dilakukan intervensi training manajemen nyeri. Nilai partial eta squared kompetensi total sebesar 0,998 sampai dengan 0,996 yang berarti ada pengaruh kuat intervensi terhadap peningkatan nilai kompetensi total manajemen nyeri. Nilai partial eta squared pengamatan ke-1 sampai dengan ke-4 variabel kognitif sebesar 0,997 menunjukkan adanya pengaruh yang kuat intervensi training manajemen nyeri terhadap peningkatan kompetensi kognitif. Sementara itu, nilai partial eta squared pada variable afektif menunjukkan penurunan dari 0,985 di pengukuran ke-1 ke 0,983 di pegukuran ke-3. Meskipun demikian, terdapat pengaruh yang kuat intervensi training manajemen nyeri terhadap peningkatan afektif dan juga skill manajemen nyeri dengan nilai partial eta squared $>0,9$.

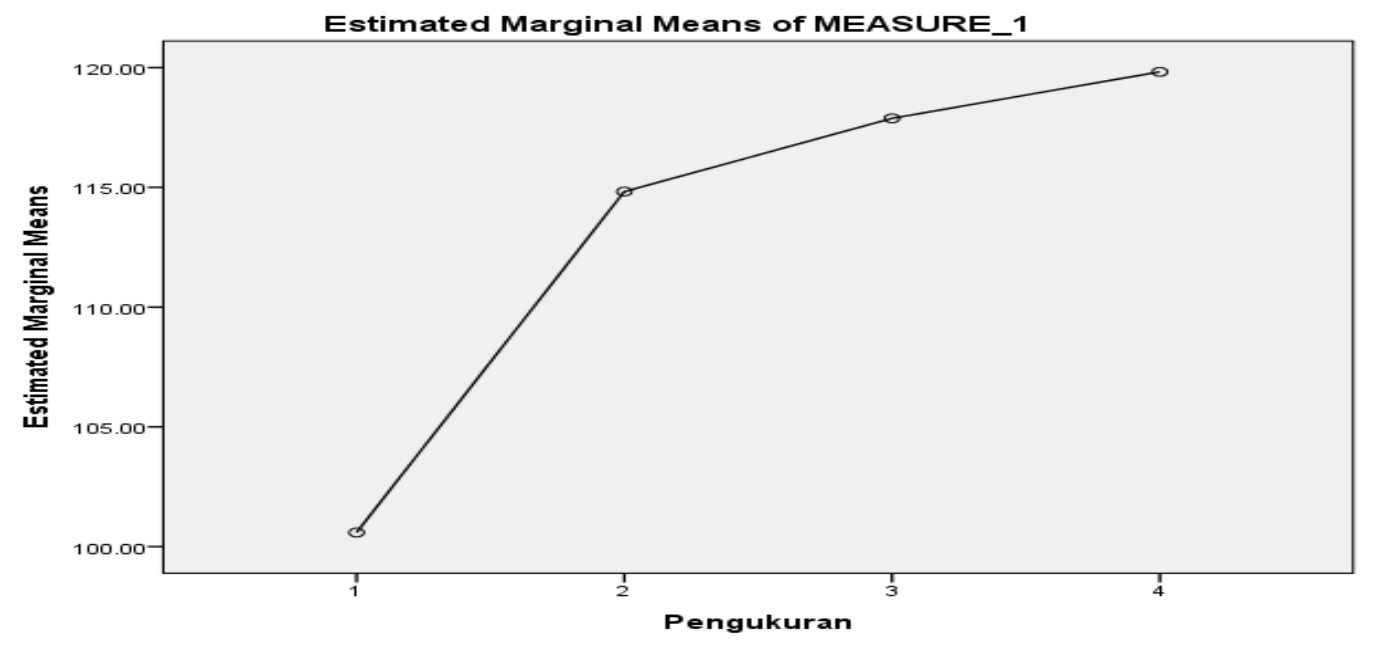

Gambar. 1

Gambaran Kenaikan Rata-Rata Kompetensi Kognitif, Afektif, dan Psikomotor Manajemen Nyeri pada Kenaikan Rata-Rata Y Tiap Pengukuran 


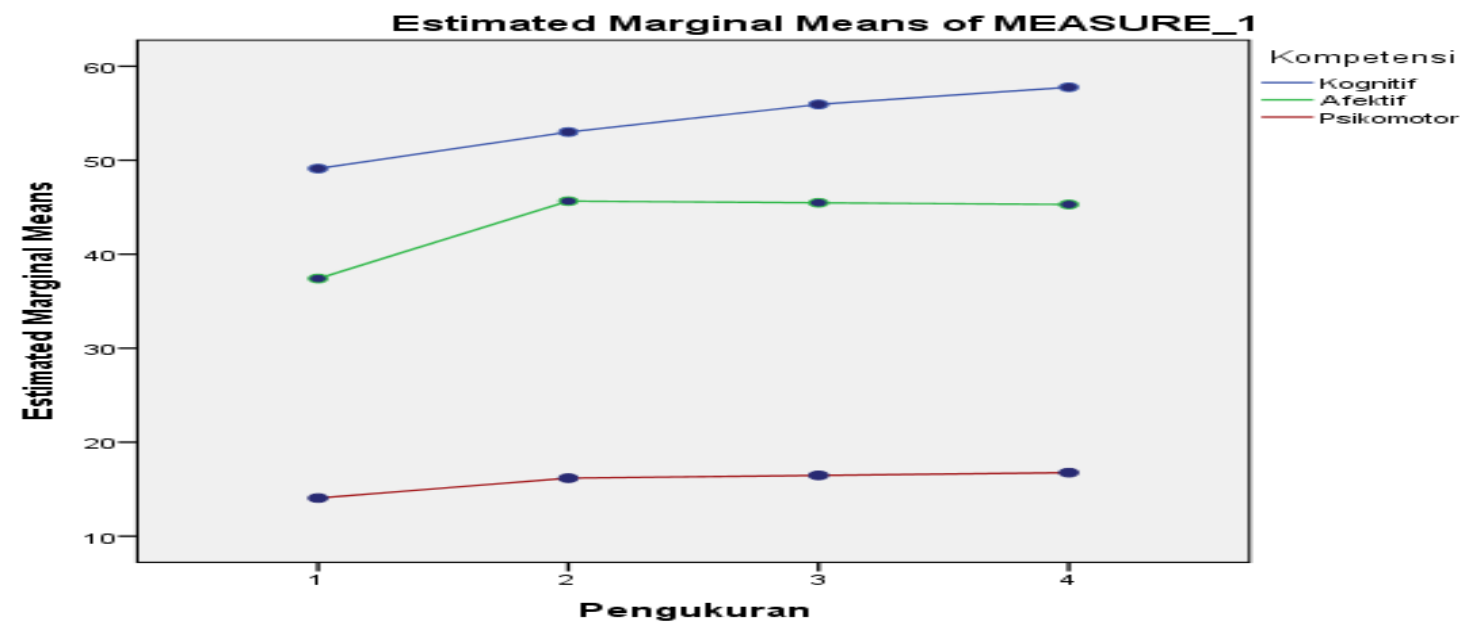

Gambar. 2

Gambaran Kenaikan Rata-Rata Kompetensi Kognitif, Afektif, dan Psikomotor Manajemen Nyeri pada Kenaikan Rata-Rata Y Tiap Pengukuran

Grafik rerata nilai kompetensi total manajemen nyeri dan subkomponen kognitif, afektif, dan skill sebelum dan setelah dilakukan intervensi off the job training manajemen nyeri menunjukkan perbedaan yang bermakna. Kedua grafik diatas menunjukkan bahwa baik kompetensi total maupun kompetensi kognitif, afektif, dan skill manajemen nyeri cenderung mengalami kenaikan dari pengukuran dan pengamatan ke-1 sebelum dilakukan intervensi ke pengukuran dan pengamatan setelah intervensi. Peningkatan yang konstan terjadi pada sub komponen kompetensi kognitif dan skill manajemen nyeri dari minggu ke-1 sampai dengan ke-4, meskipun pada variabel skill terjadi peningkatan signifikan pada minggu ke-2 tidak seperti kompetensi kognitif yang cenderung meningkat bertahap. Sementara itu, afektif responden terkait manajemen nyeri juga meningkat signifikan di minggu ke-2 meskipun cenderung sedikit mengalami penurunan pada minggu ke-3 dan ke - 4. Hasil analisis diatas menunjukkan bahwa off the job training manajemen nyeri sangat potensial dalam meningkatkan kompetensi perawat dalam manajemen nyeri terutama dalam smeningkatkan kompetensi kognitif, afektif, dan skill manajemen nyeri.

\section{PEMBAHASAN}

\section{Pengaruh Pelatihan Manajemen Nyeri terhadap Kognitif Perawat}

Dalam meningkatkan keterampilan dan mengurangi kesalahan, dirancanglah suatu sistem yang merupakan upayanya adalah melalui pelatihan. Sesuai dengan pendapat Notoatmodjo (2010) bahwa pelatihan merupakan salah satu bentuk proses pendidikan orang dewasa yang dimaksudkan untuk memperoleh pengalaman yang pada akhirnya akan menyebabkan terjadinya peningkatan pengetahuan. Sedangkan Baron dan Greenberg (Nursalam 2010) menyatakan bahwa pelatihan merupakan proses secara sistemik bagi individu untuk mendapatkan dan mengembangkan keterampilan dan pengetahuan yang dibutuhkan untuk kinerja yang lebih baik.

Hasil penelitian memperlihatkan terdapat peningkatan pengetahuan perawat setelah dilakukan pelatihan terlihat bahwa nilai rerata skor pengetahuan manajemen nyeri perawat sebelum mendapatan training manajemen nyeri sebesar 49,12 dan meningkat menjadi 57,76 setelah dilakukan training. Nilai minimum dan maksimum pengetahuan tampak meningkat mencapai 52 dan 63. Kemampuan menerapkan 
manajemen nyeri perawat juga meningkat menjadi 16,76 $\pm 1,091$ dengan nilai maksimum pengamatan mencapai 19.

Hasil penelitian mengenai ini, sama dengan hasil penelitian Rikandi (2014) bahwa hanya $19,4 \%$ perawat yang mempunyai pengetahuan yang baik sebelum pelatihan dan meningkat menjadi 50\% setelah pelatihan. Sejalan dengan penelitian yang dilakukan Mulia (2010), di RS Tugu Ibu Depok, mengatakan bahwa ada perbedaan pemahaman perawat pelaksana setelah pelatihan pada kelompok eksperimen dibandingkan dan kelompok kontrol. Penelitian yang dilakukan oleh Zhanget al. (2008), tentang efek pelatihan manajemen nyeri terhadap pengetahuan dan sikap perawat di China. Zhang mengatakan bahwa peningkatan pengetahuan dan sikap perawat sebanyak $15,6 \%$ ketika dievaluasi satu bulan setelah dilakukan pelatihan. Penelitian yang dilakukan oleh Abdalrahim et al, (2011) juga mengatakan bahwa setelah dilakukan pelatihan terdapat peningkatan pengetahuan perawat dan terjadi perbaikan dalam pendokumentasian.

Pengetahuan merupakan domain yang penting dalam membangun perilaku seseorang sehingga mempunyai landasan untuk berperilaku sesuai pengetahuan yang dimilikinya terhadap suatu hal. Perilaku yang yang didasari oleh pengetahuan akan lebih mengarahkan seseorang untuk berbuat lebih baik dalam menjalankan tugas ataupun pekerjaannya. Belajar adalah proses dimana suatu perilaku muncul atau berubah karena adanya respon terhadap situasi (Sudrajat, 2008). Menurut Ellis, Harley (2001) pengetahuan tidak terlepas dari kemampuan seseorang untuk belajar yang dipengaruhi oleh umur, jenis kelamin, tingkat pendidikan, pengalaman hidup dan gaya belajar.

Pendapat diatas sesuai dengan data karakteristik responden pada penelitian ini, dimana meannya 30,29 termasuk kedalam usia dewasa awal yaitu 23 - 40 tahun dan hanya $16,7 \%$ perawat yang termasuk dalam kategori dewasa (Dep Kes, 2010). Usia mempengaruhi daya tangkap dan pola fikir seseorang, menurut Djaali (2007) usia mempengaruhi terhadap daya tangkap dan pola fikir seseorang. Peningkatan umur akan semakin mengembangkan daya tangkap dan pola fikir seseorang sehingga pengetahuan yang dimilikinya semakin membaik. Menurut Dep Kes (2010) usia dewasa awal adalah usia dimana seseorang mulai meniti karirnya, sedangkan pada usia dewasa akhir adalah tahap mempertahankan apa yang sudah didapatkan.

Namun, peneliti berpendapat meskipun terdapat perbedaan yang signifikan mengenai pengetahuan, tindak lanjut program pelatihan yang berkesinambungan dengan evaluasi secara periodik perlu dilakukan sehingga hasil pelatihan ini dapat diterapkan dalam pemberian asuhan keperawatan. Berdasarkan pendapat yang dikemukakan oleh Morrison (2001), efektifitas ingatan terhadap objek pelatihan dapat dioptimalkan dengan melakukan pelatihan lanjutan maksimal 6 bulan dari pelatihan sebelumnya, karena reaksi pengetahuan pada staf setelah mendapatkan pelatihan berada pada rentang tersebut.

\section{Pengaruh Pelatihan Manajemen Nyeri terhadap Afektif Perawat}

Hasil penelitian menunjukkan bahwa ada peningkatan sikap perawat dalam melaksanakan manajemen nyeri. Kenaikan skor setelah dilakukan training manajemen nyeri tampak pada variable yaitu sikap dalam manajemen nyeri. Rerata sikap perawat

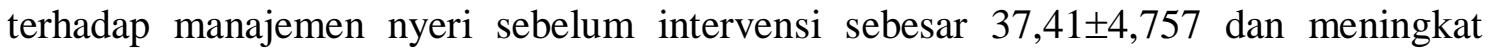
menjadi 45,29 $\pm 6,060$. 
Salah satu ciri-ciri sikap yang dikemukakan oleh Notoatmodjo (2006) bahwa sikap bukan dibawa dari lahir melainkan dapat dibentuk atau dipelajari dan sikap dapat berubah bila terdapat keadaan dan syarat-syarat tertentu. Pendapat inilah yang mendasari peneliti berkeyakinan bahwa pelatihan sebagai sarana meningkatkan pengetahuan perawat dapat meningkatkan sikap perawat kearah yang lebih positif. Pendapat ini diperkuat oleh teori yang dikemukan Azwar (1995) bahwa salah satu komponen pembentukan sikap adalah komponen kognitif, yang terdiri dari pengetahuan. Pengetahuan inilah yang akan membentuk keyakinan dan pendapat tertentu tentang objek sikap.

Perbandingan perubahan sikap perawat sebelum dan sesudah pelatihan terlihat dari peningkatan nilai rerata sikap perawat .Secara umum terjadi sikap perawat dalam manajemen nyeri. Secara keseluruhan terjadi peningkatan sikap perawat kearah yang lebih positif setelah dilakukan pelatihan.

Pengamatan yang peneliti lakukan diruangan, bahwa peningkatan sikap perawat terhadap manajemen nyeri ini juga didukung oleh penguatan dari kepala ruangan. Sebagai rumah sakit yang baru yang sedang mempersiapkan diri untuk akreditasi, perawat dituntut untuk melaksanakan manajemen nyeri sebagai salah satu indikator penilaian akreditasi, dimana fokus penilaiannya adalah terhadap pasien. Asumsi peneliti ini sesuai dengan pendapat yang dikemukakan oleh Azwar (1995) bahwa perubahan sikap dipengaruhi oleh pengalaman pribadi, pengaruh kebudayaan, pengaruh orang lain yang dianggap penting dan pengaruh emosi dalam diri individu.

Penelitian Al Shaer et al, (2011) mengatakan bahwa sikap perawat memiliki pengaruh yang kuat terhadap keberhasilan pelaksanaan manajemen nyeri. Sikap adalah respon seseorang yang masih tertutup terhadap suatu stimulus atau objek. Manifestasi dari sikap tidak dapat langsung dilihat namun hanya bisa ditafsirkan terlebih dahulu dari perilaku yang tertutup. Sikap merupakan konsep yang sangat penting dalam komponen sosio-psikologis karena merupakan kecendrungan bertindak dan berpersepsi. Sikap adalah bentuk respon tertutup seseorang terhadap stimulus atau objek tertentu, yang sudah melibatkan faktor pendapat dan emosi yang bersangkutan seperti: senang/tidak senang, setuju / tidak setuju, baik / tidak baik (Notoadmodjo, 2007). Penelitian Al Shaer et al, (2011) mengatakan bahwa sikap perawat memiliki pengaruh yang kuat terhadap keberhasilan pelaksanaan manajemen nyeri. Pelatihan manajemen nyeri berpengaruh terhadap sikap perawat ke arah positif, sehingga pelatihan perlu dilakukan secara rutin dan terencana.

\section{Pengaruh Pelatihan Manajemen Nyeri terhadap Skil Manajemen Nyeri oleh Perawat}

Hasil penelitian menunjukkan ada peningkatan s manajemen nyeri oleh perawat ( $p$ value $=0,000 \mathrm{p}<0,005)$. Mengutip pernyataan yang dikemukan oleh Roger dalam Notoatmodjo (2007), bahwa perilaku yang didasari oleh pengetahuan, kesadaran dan sikap yang positif akan bersifat langgeng (lost lasting). Pelatihan manajemen nyeri diharapkan dapat meningkatkan pengetahuan dan sikap perawat, sehingga penerapan manajemen nyeri dapat lebih baik.

Hasil observasi penerapan manajemen nyeri yang dilakukan perawat didapatkan rerata penerapan manajemen nyeri sebelum pelatihan adalah dengan mean 14,06. Penerapan manajemen nyeri setelah pelatihan mengalami peningkatan dengan nilai rerata untuk penerapan adalah dengan mean 16,76 . 
Berdasarkan analisis hasil observasi diatas dapat disimpulkan bahwa penerapan manajemen nyeri oleh perawat diruang penyakit dalam dewasa rumah sakit padang pariaman secara statistik terdapat perbedaan setelah dilakukan intervensi off job Hasil penerapan manajemen nyeri ini hampir sama dengan tingkat pengetahuan perawat sebelum pelatihan. Tingkat pengetahuan mempengaruhi kemampuan perawat dalam melakukan tindakan dalam hal ini adalah penerapan manajemen nyeri. Pendapat ini didukung oleh pendapat Notoatmodjo (2009) yang menyatakan bahwa pengetahuan yang menunjang keterampilan perlu diberikan agar staf dapat melakukan tugasnya berdasarkan teori-teori yang dapat dipertanggung jawabkan.

Penelitian yang dilakukan Al-Shaer et al, (2011) mengatakan hasil pengetahuan dan pengkajian nyeri merupakan komponen dasar untuk melaksanakan tindakkan keperawatan. Peneliti berasumsi bahwa rendahnya penerapan manajemen nyeri sebelum pelatihan disebabkan oleh pengetahuan perawat yang kurang mengenai manajemen nyeri itu sendiri. Sesuai dengan penelitian Zhang et al, (2013) mengatakan bahwa pelaksanaan program pendidikan manajemen nyeri, terutama untuk perawat yang bertindak sebagai pemberi pelayanan lini pertama, sangat dibutuhkan. Pengetahuan dan sikap yang akurat tentang manajemen nyeri merupakan prinsip penting dalam praktek keperawatan karena secara langsung mempunyai dampak terhadap pasien.

Pendapat yang dikemukakan oleh Rivai, Sagala (2009) menyatakan jika kemampuan peserta pelatihan meningkat secara signifikan, artinya program pelatihan secara aktual menyebabkan terjadinya perbedaan kemampuan. Sejalan dengan pendapat dari Notoatmodjo (2010) yang menyatakan bahwa pengetahuan atau kognitif merupakan domain yang sangat penting dalam membentuk tindakan seseorang dan pengetahuan yang mendasari perilaku akan membuat perilaku tersebut menjadi lebih langgeng.

Berdasarkan pendapat diatas peneliti berasumsi bahwa terjadinya peningkatan penerapan manajemn nyeri setelah pelatihan disebabkan karena perawat sudah mempunyai landasan teori dalam melakukan tindakan. Tindakan penerapan manajemen nyeri dilakukan berdasarkan pengetahuan yang diterima saat pelatihan. Pendapat ini diperkuat oleh Marquis, Huston (2012) mendefinisikan pelatihan sebagai metode yang terorganisir untuk memastikan bahwa individu memiliki pengetahuan dan keterampilan tertentu sehingga dapat meningkatkan kemampuan afektif, motor dan kognitif yang pada akhirnya meningkatkan produktifitas.

Evaluasi dampak program pelatihan yang diberikan perlu diiringi dengan suatu pelatihan yang berkesinambungan, terprogram dan terencana sesuai peningkatan kebutuhan perawat atas hal spesifik yang menjadi tuntutan kinerja perawat dalam melaksanakan manajemen nyeri. Pengetahuan dan ilmu yang baru terkait manajemnen nyeri perlu diaplikasikan dalam tatanan pelayanan dalam rangka meningkatkan mutu pelayanan keperawatan. Penataan ulang SOP manajemen nyeri yang disyahkan oleh pimpinan RS dapat menjadi upaya positif untuk mengoptimalkan transfer pengetahuan dalam pekerjaan perawat secara lebih nyata. Menurut Mc. Cutcheon et al, Nursalam (2010) Bahwa sumber daya manusia pada bagian keperawatan memiliki kebutuhan yang besar untuk mendapatkan pendidikan dan pelatihan berkelanjutan dalam berbagai jenjang untuk mendukung penerapan dalam melakukan tindakan. 


\section{SIMPULAN}

Tingkat Kognitif, Afektif dan skill manajemen nyeri perawat sesudah dilakukan pelatihan di ruang penyakit dalam dewasa mengalami perubahan dibandingkan dengan sebelum dilaksanakan pelatihan

Terdapat pengaruh pelatihan manajemen nyeri bagi perawat terhadap pengetahuan, sikap dan penerapan manajemen nyeri di ruang penyakit dalam dewasa pada rumah sakit padang pariaman

Sangat potensial dalam peningkatan kompetensi perawat dalammanajemen nyeri teruma dalam meningkatkan pengetahuan, sikap dan skil manajemen nyeri sesuai dengan hasil analisis yang dilakukan.

\section{SARAN}

1. Membuat program pelatihan manajemen nyeri secara berkesinambungan minimal dalam 6 bulan sekali bagi tenaga keperawatan.

2. Melalui kepala ruangan melakukan monitoring evaluasi setiap timbang terima mengenai penerapan manajemen nyeri di ruangan.

3. Mempertahankan sikap keperawatann yang terdapat dalam manajemen nyeri untuk melaksanakan manajemen nyeri sehingga dapat meningkatkan mutu pelayanan keperawatan.

4. Bagi kepala bidang hendaknya membuat format relaksasi, distraksi, yang bisa menjadi pedoman dalam manajemen nyeri

5. Membuat alur tata laksana nyeri yang mendapat persetujan dari direktur rumah sakit yang berguna sebagai acuan dalam tata laksana manajemen nyeri

6. Bagi Peneliti selanjutnyaperlu dilakukan penelitian berkelanjutan untuk melihat efektifitas pelatihan manajemen nyeri bagi perawat terhadap penurunan skala nyeri pada pasien

\section{DAFTAR PUSTAKA}

Abdalrahim, M.S., Majali, S.A., Stomberg, M.W., \& Bergbom, I. (2011). The Effect of Postoperative Pain Management Program on Improving Nurses Knowledge and Attitudes Toward Pain. Nurse Education in Practice, 11(4), 250-255

Al Syaer. (2011). Komunikasi dalam keperawatan. Jakarta: Salemba Medika

Al-Shaer.D., Hill. P.D., \& Anderson. M.A. (2011). Nurses Knowledge and Attitudes Regarding Pain Assessment and Intervention. Research for Practice, 20(1), 7-11

Amelia D. M. (2014). Improving Nurses Pain Management in the Post Anasthesia Care Unit http//www.mjournal.com/jornal of nursing/pain management pada tanggal 15 maret 2018 pkl. $21.32 \mathrm{wib}$

Azwar. (1995). Sikap Manusia, Teori dan Pengukurannya. Yogyakarta: Pustaka Pelajar offset

Betz \& Sowden. (2012). Buku Saku Keperawatan. Jakarta: EGC

Casey \& Georgina. (2011). Pain - the Fifth Vital Sign. New Zealand: Continuing Professional Development

Chuandy. (2015). Konsep Pain-Free Hospital. Studylibid.com https: //studylibid.com.pada tanggal 05 maret 2018 pkl. $13.00 \mathrm{wib}$

Djaali (2007). Psikologi Pendidikan. Jakarta: PT. Bumi Aksara

DPD PORMIKI DKI Jakarta. (2017). Standar Nasional Akreditasi RS (SNARS) ed.1 Tahun 2017. http://www.pormiki-dki.org/2016-04-20-03-11-28/daftar-bukukumpulan-peraturan/84-standar-nasional-akreditasi-rs-snars-ed-1-tahun-2017 
Ellis dan Harley. (2001). Peran Ganda dan Dukungan Sosial dengan Stres Kerja pada Perawat

Ivancevich. (2008). Perilaku dan Manajemen Organisasi. Jakarta: Erlangga

Kumar, Vinay, Abbas K Abdul, Aster C. Jon. (2015). Buku Ajar: Patologi. Robinson. Jakarta: EGC

Marquis dan Huston. (2012). Kepemimpinan dan Manajemen Keperawatan Teori dan Aplikasi. Jakarta: EGC

Marth, RA. (2016). Pakar Teori Keperawatan dan Karya Mereka, Edisi Indonesia ke 8 volume 2: Elsevier

Martini, F. (2006). Fundamentals of Anatomy \& Physiologi. Sevent Edition. Pearson, Benjamin Cumming

Morrison. (2001). Carring and communicating: Hubungan interpersonal dalam keperawatan. Jakarta: EGC

Mulia, S. (2010). Pengaruh Pelatihan Keselamatan Pasien terhadap Pemahaman Perawat Pelaksana Mengenai Penerapan Keselamatan Pasien di RS Tugu Ibu Depok (Tesis Magister, Tidak Dipublikasikan)

Notoadmojo. (2006). Manusia dan Sikap Manusia. Jakarta: Rhineka cipta

Notoadmojo. (2007). Promosi Kesehatan dan Ilmu Prilaku. Jakarta: Rhineka cipta

Notoadmojo. (2009). Pengembangan Sumber Daya Manusia. Jakarta: Rhineka cipta

Notoadmojo. (2010). Ilmu Prilaku Kesehatan. Jakarta: Rhineka cipta

Nursalam. (2012). Manajemen Keperawatan: Aplikasi dalam Praktek Keperawatan Profesional, Edisi 3: Salemba Medika

Potter \& Perry. (2011). Fundamental Keperwatan. Buku 2 Edisi 7. Jakarta: Salemba Medika

Rivai \& sagala. (2009). Manajemen Sumber Daya Manusia untuk Perusahaan dari Teori ke Praktek. Jakarta: PT. Raja grafindo

Smeltzer \& Bare. (2013). Buku Ajar Keperawatan Medikal Bedah. Jakarta: EGC

Sudrajat. (2008). Hubungan Tingkat Pendidikan dan Lamanya Kerja dengan Kinerja Perawat di Rumah Sakit Kabupaten Sorong

Tamsuri, A. (2007). Konsep dan Penatalaksanaan Nyeri. Jakarta: EGC

Watson, J. (2013). Aplikasi Model Konseptual Caring http//www.academia.edu pada tanggal 15 maret 2018 pukul 22.05 wib

Zhang Hu-Chun, RN, MSN, Lily Hsu, RN, MSN, Bi Rong Zou, RN, Jiang - Fang Li, RN, Hong Ying Wang, RN and Jue Hang, RN. (2013). Effect of a Pain Education Program on Nurses' Pain Knowledge, Attitudes and Pain Assessment Practices in China. http//www.mjournal.com/Jornal of Nursing/Pain Management 